\title{
CASH WAQF LINKED SUKUK: ISSUES, CHALLENGES AND FUTURE DIRECTION IN INDONESIA
}

\author{
Rozaq Muhammad Yasin ${ }^{\text {a }}$ \\ ${ }^{a}$ Department of Management, Faculty of Economics and Business, University of Muria Kudus \\ Email: rozaq.yasin@umk.ac.id ${ }^{\mathrm{a}}$
}

\begin{abstract}
ARTICLE HISTORY
Received:

19 January 2021

Revised

8 April 2021

Accepted:

31 May 2021

Online available:

30 June 2021

Keywords:

Cash Waqf Link Sukuk, Waqf Fundraising,

Issue,

Challenges,

Future Direction.

*Correspondence:

Name:

Rozaq M. Yasin

E-mail:

rozaq.yasin@umk.ac.id

ABSTRACT

Cash Waqf Linked Sukuk (CWLS) is the first innovation sukuk-based modern waqf fundraising development issued by the Indonesian government in 2020. People who prefer to channel their social funds in zakat, infaq, and shodaqah make CWLS less desirable. This paper evaluates the issues, challenges and future direction from the issuance of the CWLS series SWRO01 by the Indonesian government. This study used systematic literature review analysis and used Publish or Perish software with Google Scholar as the database. A total of 48 articles published from 2016 to 2021 were selected. Object of this research is the SWR001 series. Systematic data analysis is used to define relevant themes within the topic. The dominance of individual waqf $(99.6 \%)$ shows that even though SWR001 was offered during the Covid-19 pandemic, it is still in demand by investors (wakif). Even so, less than optimal sales results make nadzir having to re-evaluate the implementation of social programs that had been planned before. Issues and challenges in the development of CWLS products include relatively new products, limited distribution partners and nadzir, low coupons, lack of public understanding, contracts, and incomplete literacy causing the potential wakif not to be maximized. In the future, to increase the CWLS collection, stakeholders is need to ensure the information and mobilization through word-of mouth with the objective to create a positive word of CWLS. Improving communication strategies, ease of service and professionalism nadzir to be very important to do.
\end{abstract}

\section{INTRODUCTION}

Fatwa of the Indonesian Ulama Council in 2002 stipulated that the legal cash waqf was acceptable. After that the government issued Law number 41 year 2004 concerning waqf which regulates term waqf (mua'qqat which accommodates the Hanafiyyah mazhab), waqf for movable objects such as money, precious metals, securities, vehicles, intellectual property rights, lease rights, and other movable objects in accordance with sharia provisions and the prevailing laws and regulations, a more professional nadzir and so on. The emergence of this law had a major impact on the dynamics of waqf in Indonesia (Dirjen Bimas Islam, 2013). 
The government, which has committed to participate in developing Islamic financial instruments, also offers a new creative financing product of social investment, namely Cash Waqf Link Sukuk (CWLS). The first CWLS was discussed at the 2018 IMF-World Bank annual meeting in Bali but could only be issued in 2020. The Indonesian government has issued two types of CWLS, namely SW001 series by private placement and SWR001 series by retail. Imam Teguh Saptono as deputy chairman of the Indonesian Waqf Board said that the CWLS scheme is the first waqf instrument to be managed using State Sharia Securities (Tanjung, 2020).

Cash Waqf Link Sukuk is defined as State Sharia Securities (SBSN) issued under socially responsible based investment scheme for investment in waqf fund management institutions (DJPPR Kemenkeu, 2020). CWLS was built for wakif able to provide temporary and perpetual waqf that is safe, productive and in accordance with Islamic sharia. CWLS is also expected to create inclusive and sustainable economic growth, namely eradicating poverty, reducing inequality (Rahayu \& Agustianto, 2020) and increasing the productivity of existing waqf assets (Paul \& Faudji, 2020).

The increasingly rapid development of waqf fundraising innovations will certainly face issues, challenges and future direction. There are still many people who prefer to channel their funds for zakat, infaq, and shodaqah rather than cash waqf (Alifiandy \& Sukmana, 2020; Shahimi et al., 2013) can be a challenge itself in campaigning for the cash waqf movement. Since the launch of this instrument, the benefits of CWLS have not been maximally felt as expected because the maximum collection targets have not been realized (DJPPR Kemenkeu, 2020).

This study aims to evaluate the CWLS practices that have been published by the government, and then propose improvements that can be made for future development of CWLS instruments. This topic is very interesting to study considering that CWLS innovation is still very new and has the opportunity to develop in the future. CWLS is the first instrument in the world aims as a supporting machine in encouraging the development of the potential for waqf cash in Indonesia (Putri et al., 2020). This study tries to discuss the issues, challenges, and future direction from the practice of SWR001 series that has been issued by the Indonesian government for success CWLS instruments in the future.

\section{LITERATURE REVIEW}

Waqf according to Indonesian Waqf Law Number 41 year 2004 is a legal act of wakif to separate and/or give part of his property to be used forever or for a certain period of time in accordance with his interests for the purposes of worship and/or general welfare according to sharia. Waqf is an endowment made by the wealthy to serve the needy. Basically, four parties contribute with waqf property as follows (Dirjen Bimas Islam, 2013): 1) wakif (endower); 2) nadzir (waqf manager) who is 
obliged to maintain the fund in a way that keep the original amount; 3) mawquf 'alaih (beneficiaries); and 4) mawquf (property or cash as property).

Waqf system shows the nature of Islam in giving public goods like education, healthy, and economics (Haron et al., 2016). The legal basis used to explain the concept of waqf is in Surah Ali-Imron (3) verse 92: "You never come to virtue (which is perfect), before you spend part of the wealth you love."

Waqf as an Islamic public finance instrument can be seen as a great potential mechanisms that play a significant role in generating a prominent source of financing for the state and for the needs of the Muslim ummah who are complex and growing (Puad et al., 2014). Waqf becomes practice that has great benefits and will not lose its reward as long as the waqf assets can still be used for the welfare of the people.

In the early stages of its development, the waqf sector requires new thinking to develop (Nezliani, 2020). This momentum was captured by the government to expand the scope of waqf, which was originally only in the form of fixed assets and then added with movable assets such as money (Hudzaifah, 2019). Cash waqf is an alternative method for Muslims to achieve modern economics development (Haron et al., 2016). Cash waqf is a unique opportunity for investment creation in the fields of religion, education, health and other social services (Paul \& Faudji, 2020)

The existence of the Indonesian Waqf Board that regulates waqf in Indonesia is expected to be able to accelerate the development of better utilization of waqf assets and the potential of waqf. The Indonesian Waqf Board, which is given the authority as nadzir to manage and develop waqf assets on a national and international scale, seeks to create a cash waqf program with investments that are safe, profitable, and in accordance with sharia and statutory regulations. The Indonesian Waqf Board collaborates with the Ministry of Religion, Ministry of Finance, Bank Indonesia, Productive Waqf Forum, and Financial Institutions Recipient of cash waqf to make a cash waqf program called Cash Waqf Linked Sukuk (Paul \& Faudji, 2020)

Even so, cash waqf is still not well understood by the community because it is considered not obligatory like zakat (Osman et al., 2016). The imbalance between expected amount of potential waqf and the accumulated waqf funds is a challenge in itself (Hiyanti, et al., 2020). Cash waqf is only done by people who have high religiosity and also high trust in nadzir. Knowledge, income, community culture and promotion affect wakif's desire for cash waqf (Hudzaifah, 2019). Attitude also effect on the willingness of wakif in cash representation (Alifiandy \& Sukmana, 2020). Cash waqf investors will be more interested if they are able to see and control the management of cash waqf they pay (Osman et al., 2016).

The publication of CWLS SWRO01 series is government's step in integrating sukuk and waqf as an interesting innovation in Islamic finance. Sukuk have the potential as an instrument to mobilize funds, while waqf has the capacity to generate income from productive financial activities (Ilmiah, 2019). Sukuk-waqf is an 
innovation for economic sustainability, a panacea to address income gaps, a charity fundraising brand, and modern schemes to develop waqf assets. There are two types of waqf sukuk, namely sukuk linked waqf and waqf linked sukuk (Musari, 2019). The government applies waqf linked sukuk scheme in issuance of SWR001.

Cash Waqf Linked Sukuk is a valuable state sharia certificate in the form of cash waqf-based sukuk. The collected waqf funds will be invested in safe and riskfree investment (sukuk) so that the funds generated by CWLS can be used to help provide social facilities for the people. The large number of waqf assets that have not been used productively is due to a lack of development funds (Himam \& Umam, 2018) can be bridged with this CWLS instrument.

The objectives of the Retail CWLS issuance according to the Ministry of Finance are 1) facilitating the public to have safe and productive waqf money; 2) developing innovations in finance and social investment in Indonesia; 3) promote inclusive and sustainable economic growth; 4) strengthening the cash waqf ecosystem in Indonesia; 5) supporting the National Waqf Movement, assisting the development of social investment, and the development of productive waqf in Indonesia.

Nadzir CWLS is a party that acts in accordance with statutory provisions to manage cash waqf funds invested in Sukuk Waqf issued by government. The social projects/activities resulting from the CWLS SWR001 series are non-APBN social projects/activities proposed and implemented by nadzir whose funding comes from nominal value of SWR001 sukuk waqf (perpetual wakif) and CWLS Series SWR001 rewards/coupons.

Every new product released always faces issues, challenges and future direction. According to Harrison, issues is any development, usually in the public arena, which if it continue could significantly affect the operations of failure interests of the organization or product (Kriyantono, 2012). While a challenge is a thing or form of business that has the aim of arousing abilities (Prayetno, 2015). Future direction is defined as an estimate of something that might happen in the future. These activities should be seen as an input in making further plans.

Waqf issues have taken this significant place due to the efforts have been done by contemporary scholars, revealing the benefits associated with Waqf practices including its applications in contemporary society plus addressing associated challenges. Most of the previous studies found that cash waqf is an efficient instrument that can be an alternative to poverty alleviation, because these initiatives require huge funds that cannot be obtained in total by the government (Aldeen et al., 2020).

According to Putri et al. (2020) the cause of the delay in collecting CWLS fund investment in supporting the economic development of the people is seen from three perspectives, namely nadzir, regulator and wakif. The majority of respondents agreed that the nadzir problem was the main problem that had to be resolved so that 
the management of CWLS could support the economic independence of the community. Cash waqf regulation discourages Islamic Bank-nadzir report and needs coordination behavior to practice cash waqf transparency by providing regular report. Cash waqf regulation in Indonesia provides a lack of justifications in terms of cash waqf supervisory and governance. Those pieces of evidence enhance the facts that cash waqf fails to meet the stakeholders' expectation (Utomo et al., 2020)

In addition, according to Iman et al. (2021) that attitudes of wakif's, subjective norms, and values of religiosity were able to influence waqf behavior in making decisions to do cash waqf. In fact, according to Nurjannah and Abdullah (2020), cash waqf instruments can be a solution for the economy during the Covid-19 pandemic. Even the Cash Waqf Linked Sukuk Model under salam issued by the Central Bank of Bahrain using ba'i salam contract is categorized as green sukuk model (Yunita, 2020).

\section{RESEARCH METHODS}

The method of this paper is systematic literature review (SLR) technique that emphasizes the use of literature as the primary data source. The systematic literature review technique consist of three step as process of identifying, assessing, and interpreting all research question. The first step is to find previous research journals that are relevant to the purpose of this study using the help of Publish or Perish (PoP) software. The PoP keyword used is cash waqf using a data base from Google Scholar to produce 300 papers from 2016 to 2021. From these results 48 relevant papers were selected in this study.

The second step, the various data and research work were summarized to obtain interpretation of the data until writing it in a research report. To do this, we use the help of the Microsoft Excel software to categorize the issues, challenges and future expectations of the CWLS instrument. In addition, the data is also a memorandum of information on the retail CWLS series SWR001 issued by the Directorate General of Financing and Risk Management of the Ministry of Finance in 2020.

The third step, the author makes observations and analyzes existing data to observe issues, challenges and future direction related to the CWLS instrument using various relevant literature and journals. Cash Waqf Linked Sukuk SWR001 series was chosen because it was the first retail cash waqf linked sukuk instrument ever issued by the government.

\section{RESULT AND ANALYSIS}

The government officially offered the Retail Cash Waqf Linked Sukuk SWR001 series to individuals and institutions in October 2020. The issuance of the Retail CWLS SWR001 series is a form of the Government's commitment to support the National Waqf Movement, assisting the development of social investment and the 
development of productive waqf in Indonesia. CWLS involves five stakeholders, namely 1) Bank Indonesia as an accelerator in encouraging the implementation of CWLS and Custodian Banks; 2) Indonesian Waqf Board (BWI) as regulator, leader and nadzir who manages CWLS; 3) Ministry of Finance as an sukuk issuer and fund manager in the real sector; 4) Nadzir Waqf Productive as the Indonesian Waqf Board Partner who raises waqf funds. 5) sharia banks as Islamic Financial Institutions Receiving Cash Waqf (LKS-PWU) and operational banks for Indonesian Waqf Bodies (DJPPR Kemenkeu, 2020).

SWR001 uses the wakalah contract scheme, using State Property and the 2020 development project as underlying assets. CWLS SWR001 series involves seven nadzir waqf namely LAZISNU, LAZISMU, BSM Umat Foundation, Baitul Maal Muamalat, Salman Waqf ITB, Hasanah Titik Foundation, and Dompet Dhuafa. Each nadzir has a different social activity program. For example, the BSM Umat Foundation assumes that the SWR001 Principal Value collected is IDR50,000,000,000 with a projection of a coupon of IDR150,000,000 each month, the BSM Umat Foundation plans to carry out social activities in the form of rice seed breeding in Central Lampung, parent assistance beef cattle in Trenggalek Regency, educational scholarships and hearing aid assistance for deaf people in Indonesia. However, in reality the BSM Umat Foundation was only able to realize the collection of SWRO01 of IDR10,820,000,000 (21.64\%) from the initial target. So like it or not, the planned social programs will also be readjusted. Details of the results of the issuance of SWR001 can be seen in Table 1 below.

The dominance of individual waqf (99.6\%) shows that even though SWR001 was offered during the Covid-19 pandemic, it is still in demand by investors (wakif). The results of the final collection of the SWR001 series amounting to IDR14,912,000,000 are still far from the target funding requirements proposed by the seven nadzir of IDR134,000,000,000 to carry out their social programs. So that nadzir needs to make adjustments about what programs will be realized from the results of the issuance of SWRO01.

Table 1

Sales Result of SWR001

\begin{tabular}{cll}
\hline No & Description & Information \\
\hline 1 & Individual Wakif & 1,037 People \\
2 & Institution Wakif & 4 People \\
3 & CWLS investment nominal & IDR14,912,000,000 \\
4 & Yields & $5.5 \%$ (Fixed Coupon) \\
5 & Distribution Partners & 4 Islamic commercial banks (BSM, BNIS, BRIS, BMI) \\
6 & Tenor & 2 (two) year \\
7 & Underlying Assets & State Property and Ministry / Institution Project / \\
& & Activities in the 2020 State Budget.
\end{tabular}

Source: Press Release of the Director General of Financing and Risk Management (2020) 
The nominal value per unit of SWR001 is set at IDR1,000,000 with the rate of return offered at 5.5\% per year (fixed coupon). Distribution partner of the issuance of CWLS series SWR001, namely PT. Bank BRI Syariah, PT. Bank Muamalat Indonesia, PT. Bank Syariah Mandiri, and PT. Bank BNI Syariah. The term of SWR001 is two years and matures on November 10, 2020.

At maturity the government is obliged to pay a nominal value of SWR001 to wakif where 1) if wakif participates temporarily, then wakif will have a nominal value that is transferred automatically to the wakif account; 2) if the investor participates perpetually (forever), then nadzir sukuk waqf series SWR001 will have rights over the nominal value. This value will be distributed to nadzir sukuk wakaf series SWR001 by distribution partners by debiting the fund accounts of SWR001 sukuk owners to be transferred to the accounts of nadzirs for further management of waqf in accordance with applicable regulations.

The assets that become the basis for the issuance of SBSN are state-owned goods in the form of land and/or buildings as well as other than land and/or buildings and the object of SBSN financing is government projects that have economic value. The project is recorded in Law No.20 of 2019 concerning the State Budget for the 2020 Fiscal Year, which is part of a program implemented by state ministries/agencies, which have received an allocation in the budget.

The results of this study reveal that there is an imbalance between the amount of potential waqf expected and the realization of the waqf funds raised. The cause of this imbalance when referring to previous research could be due to trust issues in managing funds, human resource problems, system problems (Hiyanti, et al., 2020), lack of knowledge, income, community culture and even promotion or socialization issues (Hudzaifah, 2019; Alifiandy \& Sukmana, 2020).

\section{Issues in Product Development}

Nadzir and distribution partners have not optimally collected SWR001 funds because the product is still unknown and relatively new in Indonesia. The assumption that the SWR001 product is taken from the government sukuk practice, where the distribution partners are only certain Islamic banks is a separate issue. The nadzir waqf who gets the yield from the sukuk is also determined by the government, which limits other nadzir to be able to access these returns. The suggestion that the existence of a wakif with a large nominal amount of CWLS is allowed to determine its own nadzir and for what purpose the utilization of the yields is a hot issue in the SWR001 product.

Another issue regarding the coupon which is only 5.5\% (Fixed Coupon) is considered relatively small compared to other sukuk offered by the government, making it less attractive to wakifs and nadzirs. CWLS, which are considered capable of creating a system that has the main character of resilience and stability, is still not

Published by University of Airlangga.

This is an open access article under the CC BY license (https://creativecommons.org/licenses/by-nc-sa/4.0/) 
truly proven. Waqf provides the transfer of wealth for society (Puad, et al., 2014) only traditionally understood by the community so that the innovation of the CWLS instrument is still not successful. It is necessary to carry out massive promotion and introduction so that CWLS is well known by the people. The more stakeholders involved in the CWLS promotion activities are expected to be able to increase the collection of CWLS for the next series.

Another issue that is no less important is related to the management of waqf assets in the future must be carried out by Muslims in a professional, transparent and accountable manner (Muslich, 2016). Supervision from the government, the Indonesian Waqf Board and the general public is urgently needed. So that in the future CWLS will be able to become a safe, productive and recognized model for cash waqf to support sustainable development goals (SDGs) (Aldeen et al., 2020; Musari, 2019) which is able to bring mashlahah who are able to maintain syara' goals and achieve maximum benefit for the people.

\section{Challenges of Cash Waqf Development Linked Sukuk}

Cash Waqf Link Sukuk also faces many challenges, both internally and externally. There is an extension of the offer period for one week (12 November 2020 to 20 November 2020) which can add IDR8,364,000,000 (56.1\% of total order) with the addition of 654 wakif ( $62.82 \%$ of total wakif) indicates that this instrument is still unknown to the wider community. Therefore, a more massive socialization and appropriate strategy is needed so that the CWLS instrument remains attractive to investors/wakif.

Although CWLS is able to answer the confusion in finding a productive and safe money waqf instrument. However, the culture of the community still considers that waqf can only be in the form of land or land purchases (Muslich, 2016), waqf is not an obligation like zakat (Osman et al., 2016). Lack of socialization to the public is followed by a lack of professional human resources for nadzir (Haron, et al., 2016; Rusydiana \& Rahayu, 2019). To mobilize potential cash waqf investors is still a challenge.

According to Himam and Umam (2018), there are many nadzir in Indonesia those are not certified, this is being an obstacle in applying sukuk waqf. The platform for offering CWLS instruments in the community is considered less attractive due to lack of liquidity, lack of public understanding of the CWLS instrument, and other problems regarding the use of cash waqf funds..

Moreover, the CWLS instrument issued only uses the ijarah and wakalah contracts. Whereas it still allows the government as ulil amri to give an example to the public regarding other contracts that can be applied in the sukuk instrument, for example the sukuk base project using the istishna contract construction of the national development program. CWLS can also be made in the sukuk mudharabah 
instrument which reflects a fairness sharing of risks and returns (Brahim \& Muhammad, 2020).

The results of the collection of SWR001 funds which were concentrated in western Indonesia, especially in the capital city of Jakarta and West Java, indicated that public literacy regarding the CWLS instrument was still not optimal and evenly distributed. These results are supported by research from (Putri et al., 2020) that in general the challenges faced in developing CWLS are lack of socialization, low literacy, and education to the community. Even though the higher of literacy and religiosity of the community can higher the intention to have waqf in CWLS (Hiyanti, et al., 2020).

The government, Islamic Financial Institutions Recipient of Cash Waqf (LKSPWU) and the Indonesian Waqf Board need to carry out an appropriate evaluation and promotion strategy to the public so that literacy about CWLS can be received immediately. By conducting seminars and counseling on the new instrument, it is hoped that it will increase the number of waqf and nominal waqf for the next series of CWLS which will soon be reissued by the government.

\section{Future Direction of Cash Waqf Linked Sukuk}

Waqf-based sukuk is an innovation in empowering waqf assets to be productive (Ilmiah, 2019). The birth of sukuk waqf aims to optimize cash waqf management (Aldeen et al., 2020; Paul \& Faudji, 2020). The development of social instruments such as cash waqf can help the government improve welfare and provide social services to the community (Aldeen et al., 2020). Even less, the information memorandum on CWLS series SWR001 clearly states that the returns from SWR001 will be used for the fulfillment of non-APBN social programs that are very helpful for the government.

In modern Islamic economy, sukuk waqf have three functions, such as the investment function, support the velocity of money, and a tool to reach the sustainable development (Musari, 2019). The large number of waqf assets that are not productively empowered is due to lack of funds to empower or manage these waqf assets. Financing is an important factor in empowering other waqf assets such as waqf land to make it more productive.

The low realization of sales result of SWR001 led to the threat of many social programs that had been planned by nadzir not being implemented properly. It is necessary to carry out a comprehensive evaluation of the stakeholders so that the existing potential can be utilized optimally (Nadya et al., 2018). Several strategies that can be taken to market the next series of retail waqf sukuk include offering to existing wakif that have been registered at Islamic Financial Institutions Receiving Cash Waqf (LKS-PWU), offering priority customers, holding more massive socialization, and cross selling to customers individuals and institutions (Tanjung, 
2020). Expansion of distribution partners and development of ways of ordering CWLS online so that wakif does not need to come to distribution partners.

Another view is that if the sales results of SWR001 are well realized, it can also be used to meet residential needs (Khan et al., 2019). For example, the program of Hasanah Titik Foundation nadzir will use the yield from the SWR001 sukuk waqf for the Hasanah residential waqf. Hasanah Titik Foundation stated that it would provide temporary housing until the beneficiaries had the financial capacity to live elsewhere (DJPPR Kemenkeu, 2020). The use of waqf assets to provide livable houses is an innovation and practical solution in an effort to utilize waqf funds for the welfare of the people, in this case the fulfillment of livable houses.CWLS also has the potential as an appropriate disaster recovery financing instrument. Waqf sukuk can be used to finance post-disaster infrastructure development, while the proceeds from the use of sukuk (coupons) can be channeled to achieve a variety of post-disaster needs (Faiza, 2019). Considering that several regions in Indonesia have high potential for natural disasters, this model can be developed further.

To increase the investment nominal and the CWLS wakif, it is necessary to map potential investors. The CWLS offer is developed not only for bank financial institutions, namely Conventional Banks, BUS, UUS and BPRS but includes Non-Bank Financial Institutions (insurance, pension funds, pawn shop), private companies (automotive, oil companies, mining, and others). For example, non-bank financial institutions can allocate his corporate social responsibility funds, excess liquidity, and support from the Bank's parent company (Nezliani, 2020) to invest in the SWR001 waqf sukuk. Nadzir can also take advantage of the widespread network of distribution partner offices as a means of depositing waqf funds (Ubaid, 2015).

Finally, changes in rules and laws, for example, a part of the APBN deficit is issued by government sukuk, including being financed from CWLS into the future direction. The joint efforts to encourage the transformation of an environmentally conscious society and the hereafter towards an investment-oriented society based on social investment are a great opportunity. In addition, the opportunities for CWLS can be infinite because more and more Islamic financial institutions are being followed by sharia economic study programs in both private and public universities (Rusydiana \& Rahayu, 2019) which has been established. However, from the various future directions, it is important to remember that there are issues, challenges and hopes for the future, CWLS must not violate the basic laws of Islamic rules regarding waqf.

\section{CONCLUSION}

Although the publication of SWR001 is far from the target, there is still potential to be explored. Several issues in the development of CWLS products include relatively new products, limited distribution partners and nadzir, low coupons, lack of public understanding, and problems in managing waqf assets to be more professional, transparent and accountable. Challenges in developing the CWLS 
instrument include the fact that the public is not yet well-known, the contract that continues to use ijarah and wakalah, and product literacy which is only concentrated in certain places (less comprehensive).

Future direction of CWLS is needed to ensure the information and mobilization through word-of mouth with the objective to create a positive word of CWLS. Efforts to improve services to the community through the convenience of online/digital technology to make it easier to reach wakif widely are expected to increase the realization of the CWLS Retail instrument. The biggest hope is that the offering of the Cash Waqf Link Sukuk in the future can be optimal so that many nonAPBN social programs can be realized properly. To fully utilize the benefits of Waqf for economic activities we must promotion about using CWLS as a productive and safe instrument.

In addition, this study only collect data from the Google Scholar database with one keyword without paying attention to journal indexes, predatory journals or journal languages. This research only focuses on three general things related to the CWLS instrument, namely issues, challenges and future direction. For the future agenda, researchers can multiply keywords, use other literature review approaches or criticize CWLS instruments from other perspectives.

\section{ACKNOWLEDGMENT}

Thanks to all academicians of Universitas Muria Kudus for the support and asistences to finish this article.

\section{REFERENCES}

Aldeen, K. N., Ratih, I. S., \& Herianingrum, S. (2020). Contemporary Issues on Cash Waqf: A Thematic Literature Review. International Journal of Islamic Economics and Finance (IJIEF), 3(3), 119-144. https://doi.org/10.18196/ijief.3236

Alifiandy, M. M., \& Sukmana, R. (2020). The Influence Of Planned Behaviour Theory And Knowledge Toward The Waqif Intention In Contributing Waqf. Jurnal Ekonomi Dan Bisnis Islam, 6(2), 260-272. https://doi.org/10.20473/jebis.v6i2.22624

Brahim, S. R., \& Muhammad, R. (2020). Praktik Income Smoothing dan Potensi Displaced Commercial Risk Pada Sukuk Mudharabah. Al-Mashrafiyyah, 4(2), 1-14. https://doi.org/10.24252/al-mashrafiyah.v4i2.13375

Dirjen Bimas Islam. (2013). Dinamika Perwakafan di Indonesia dan Berbagai Belahan Dunia. Direktorat Pemberdayaan Wakaf.

DJPPR. (2020). Realisasi CWLS seri SWR0001.

Faiza, N. A. R. (2019). Cash Waqf Linked Sukuk Sebagai Pembiayaan Pemulihan Bencana Alam di Indonesia.

Haro, M., Kamarudin, M. K., Fauzi, N. A. M., Ariff, M. M., \& Zainuddin, M. Z. (2016). Cash waqf collection: any potential factors to influence it? International 
Journal of Business, Economics and Law, 9(2), 27-33.

https://www.ijbel.com/wp-content/uploads/2016/05/K9_213.pdf

Himam, N. S., \& Umam, K. (2018). Modelling Sukuk Waqf For Pesantren Economic Development. Journal of Islamic Economics and Philanthropy (JIEP), 1(3), 123.

Hiyanti, H., Afiyana, I. F., Fazriah, S., Akuntansi, M., \& Padjadjaran, U. (2020). Potensi Dan Realisasi Wakaf Uang di Indonesia Tahun 2014-2018. Jurnal IImiah MEA (Manajemen, Ekonomi, Dan Akuntansi), 4(1), 80. http://www.journal.stiemb.ac.id/index.php/mea/article/view/207

Hiyanti, H., Fitrijanti, T., \& Sukmadilaga, C. (2020). Pengaruh Literasi dan Religiusitas terhadap Intensi Berwakaf pada Cash Waqf Linked Sukuk (CWLS). Jurnal IImiah MEA (Manajemen, Ekonomi, Dan Akuntansi), 4(3), 493-507. http://journal.stiemb.ac.id/index.php/mea/article/view/440

Hudzaifah, A. (2019). FACTORS INFLUENCING WILLINGNESS TO CONTRIBUTE IN CASH WAQF: CASE OF SOUTH TANGERANG, INDONESIA. KITABAH: Jurnal Akuntansi Dan Keuanga Syariah, 3(1). http://jurnal.uinsu.ac.id/index.php/JAKS/article/view/4171

IImiah, D. (2019). Optimalisasi Asset Wakaf Melalui Sukuk Wakaf di Indonesia. JESI (Jurnal Ekonomi Syariah Indonesia), 9(2), 138-146. https://ejournal.almaata.ac.id/index.php/JESI/article/view/1251

Iman, N., Santoso, A., \& Kurniawan, E. (2021). Wakif's Behavior in Money Waqf: an Approach to Theory of Planned Behavior. Ekuilibrium : Jurnal IImiah Bidang IImu Ekonomi, 16(1), 12. https://doi.org/10.24269/ekuilibrium.v16i1.3184

Khan, M. K., Zaleha, S., Rasid, A., \& Bardai, B. (2019). Waqf Cooperative Housing Model ( WCHM ) as an Innovative Solution for Affordable Housing. International Journal of Innovation and Business Strategy, 12(2), 36-48.

Kriyantono, R. (2012). Public Relation \& Crisis Management. Prenada.

Musari, K. (2019). The Evolution of Waqf and Sukuk toward Sukuk-Waqf in Modern Islamic Economy. International Journal of 'Umranic Studies, 2(1), 45-54. https://www.researchgate.net/profile/KhairunnisaMusari/publication/337702302_The_Evolution_of_Waqf_and_Sukuk_toward Sukuk-

Waqf_in_Modern_Islamic_Economy/links/5de5c175a6fdcc2837006aac/TheEvolution-of-Waqf-and-Sukuk-toward-Sukuk-Waqf-in-Modern-Islamic-Ec

Muslich, A. (2016). Peluang dan Tantangan dalam Pengelolaan Wakaf. MUADDIB: Jurnal Studi Kependidikan Dan Keislaman, 6(2), 200-218. http://journal.umpo.ac.id/index.php/muaddib/article/view/284

Nadya, P. S., Alwyni, F. A., Hadiyati, P., \& Iqbal, M. (2018). Strategy Of Optimalization Cash Waqf In Indonesia. Jurnal Syarikah, 4(2), 108-121. https://doi.org/10.30997/jsei.v4i2.1486

Nezliani, L. (2020). Analisis Peran Bank Umum Syariah sebagai Potential Investor Untuk Mengoptimalkan Cash Wakaf Link Sukuk. 1st Annual Conference on Ihtifaz: Islamic Economics, Finance, and Banking (ACI-IJIEFB) 2020, 203-218. http://seminar.uad.ac.id/index.php/ihtifaz/article/view/3630

Nurjannah, N., \& Abdullah, M. W. (2020). Cash Waqf: Economic Solution during The Covid-19 Pandemic. Fitrah: Jurnal Kajian IImu-IImu Keislaman, 6(2), 223-242. https://doi.org/10.24952/fitrah.v6i2.3058 
Osman, A. F., Mohammed, M. O., \& Fadzil, A. (2016). Factor Influencing Cash Waqf Giving Behavior: A Revised Theory Of Planned Behavior. Journal of Global Business and Social Entrepreneurship (GBSE), 1(2), 12-25. http://gbse.com.my/isimarch16/GBSE 1(2) 12-25 (March 2016).pdf

Paul, W., \& Faudji, R. (2020). Cash Waqf Linked Sukuk Dalam Optimalkan Pengelolaan Wakaf Benda Bergerak (Uang). Jurnal IImiah MEA (Manajemen, Ekonomi, Dan Akuntansi), 4(2), 1-18.

http://www.journal.stiemb.ac.id/index.php/mea/article/view/423

Pemerintah Republik Indonesia. (2020). Sukuk Wakaf Seri SWR001 (Issue September). Prayetno, A. (2015). Kerja Sama Komunitas Asean 2015 Dalam Menghadapi ATHG (Ancaman, Tantangan, Hambatan Dan Ganguan). Prosiding Seminar Nasional Fakultas IImu Sosial Dan IImu Politik, Universitas Terbuka, 577-586.

Puad, N. A., Rafdi, N., \& Shahar, W. S. S. (2014). Issues And Challenges of Waqf Instrument: A case study of MAIS. E-Proceedings of the Conference on Management and Muamalah, May, 117-128.

Putri, M. M., Tanjung, H., \& Hakiem, H. (2020). STRATEGI IMPLEMENTASI PENGELOLAAN CASH WAQF LINKED SUKU K DALAM MENDUKUNG PEMBANGUNAN EKONOMI UMAT: PENDEKATAN ANALYTIC NETWORK PROCESS (ANP). Al-Infaq: Jurnal Ekonomi Islam, 11(2), 204-225. https://www.jurnalfai-uikabogor.org/index.php/alinfaq/article/view/836

Rahayu, R. D., \& Agustianto, M. A. (2020). Analisis Implementasi Cash Waqf Linked Sukuk (CWLS) Perspektif Prinsip Ekonomi Syariah. Management of Zakat and Waqf Journal (MAZAWA), 1(2), 145-161. https://doi.org/10.15642/mzw.2020.1.2.145-161

Rusydiana, A. S., \& Rahayu, S. S. (2019). Bagaimana Strategi Pengembangan Wakaf Tunai di Indonesia? Jurnal Ekonomi Dan Bisnis Islam, 5(1), 15-33.

Shahimi, S., Mohd Marzuki, M. U., \& Embong, Z. (2013). Potential of cash Waqf for poverty alleviation in Malaysia: A system dynamics approach. Jurnal Ekonomi Malaysia, 47(2), 149-163. https://www.ukm.my/fep/jem/pdf/201347(2)/jeko_47(2)-13.pdf

Tanjung, H. H. (2020). Sukuk Wakaf Ritel Seri Pertama. BWI. https://www.bwi.go.id/5638/2020/11/02/sukuk-wakaf-ritel-seri-pertama/

Ubaid, A. (2015). Kemitraan Nazhir dengan Bank Syariah dalam Mengembangkan Wakaf Uang: Studi Perbandingan di Indonesia, Bangladesh dan Yordania. KURIOSITAS: Media Komunikasi Sosial Dan Keagamaan, 8(1), 15-24. https://ejurnal.iainpare.ac.id/index.php/kuriositas/article/view/143

Utomo, S. B., Masyita, D., \& Hastuti, F. (2020). Why Cash Waqf Fails to Meet the Expectation: Evidence from Indonesia (Issue October). Otoritas Jasa Keuangan. https://ojk.go.id/id/data-dan-statistik/research/workingpaper/Documents/WP-20-02.pdf

Yunita, P. (2020). Cash Waqf Linked Sukuk (CWLS) Model: For Indonesia Sustainable Food Security. Al-Awqaf: Jurnal Wakaf Dan Ekonomi Islam, 13(1), 59-72. https://jurnal.bwi.go.id/index.php/awqaf/article/view/96 